\title{
PEMANFAATAN AUGMENTED REALITY UNTUK GAME EDUKASI BAGI ANAK AUTIS TINGKAT SEKOLAH DASAR DI RUMAH PINTAR SALATIGA
}

\author{
Fatah Yasin Al Irsyadi \\ Fakultas Komunikasi dan Informatika, Program Studi Informatika \\ Universitas Muhammadiyah Surakarta \\ Email: fatah.yasin@ums.ac.id \\ Arini Nur Rohmah \\ Fakultas Komunikasi dan Informatika, Program Studi Informatika \\ Universitas Muhammadiyah Surakarta \\ Email: arininrohmah@gmail.com
}

\begin{abstract}
ABSTRAK
Sekolah terpadu Rumah Pintar Salatiga merupakan sekolah untuk anak berkebutuhan khusus terutama tunagrahita dan autis yang masih mengalami kendala dalam penyampaian suatu pembelajaran kepada siswa-siswa nya. Salah satunya yaitu kendala untuk penyampaian pengenalan objek. Selama ini pengenalan obyek dilakukan dengan menunjukkan gambar obyek yang akan dikenalkan. Misalnya ingin mengenalkan obyek hewan, maka guru harus menyiapkan gambar obyek tersebut pada kertas secara dua dimensi kemudian ditunjukkan pada siswa. Metode seperti ini memungkinkan para siswa mengalami kesulitan untuk mengenali obyek, karena mereka merupakan anak-anak berkebutuhan khusus tunagrahita dan autis, yang mempunyai kemampuan berfikir dibawah rata-rata manusia normal. Penelitian ini bertujuan untuk merancang dan membuat sebuah aplikasi game edukasi yang berkaitan dengan Pengenalan Obyek (PO) bagi anak autis. Game edukasi ini memanfaatkan teknologi Augmented Reality yang dijalankan pada perangkat mobile android, sehingga obyek yang ditampilkan adalah tiga dimensi (3D), menarik dan interaktif. Penelitian dilakukan di Rumah Pintar Salatiga dengan kurikulum sekolah Anak berkebutuhan Khusus sebagai acuan utamanya, terutama untuk Sekolah Dasar kelas 2. Penelitian diawali dengan wawancara terhadap para guru untuk mengetahui metode pembelajaran Pengenalan Obyek terhadap anak anak autis. Selain itu wawancara juga digunakan untuk mengetahui karakteristik dan tingkat kemampuan anak autis dalam menangkap informasi dan berkomunikasi. Pembuatan game ini menggunakan software utama Unity3D, Inkscape dan Vufori SDK.. Aplikasi ini menampilkan berbagai macam objek hewan, alat transportasi, buah dan sayur. Obyek dalam bentuk tiga dimensi (3D) akan ditampilkan sesuai dengan marker yang dipilih. Ini akan membantu para guru dan wali murid dalam menyampaikan materi dan juga anak-anak akan lebih mudah mengenali suatu obyek dengan melihat aplikasi tersebut karena menarik dan seperti nyata. Pengujian dilakukan dengan mendemokan aplikasi game edukasi ini kepada anak autis di Rumah Pintar Salatiga kemudian mereka diberi kesempatan untuk mencoba dengan didampingi guru dan wali murid. Berdasarkan hasil kuisioner yang diisi oleh para guru dan beberapa wali murid Rumah Pintar dapat dinyatakan bahwa game ini mudah dimainkan oleh anak autis. Game ini sangat menarik dan bisa digunakan oleh guru dan wali murid sebagai salah satu media pembelajaran Pengenalan Obyek.
\end{abstract}

Kata kunci: game edukasi, autis, augmented reality, unity3D, inkscape, vuforia.

\section{ABSTRACT}

Smart House Salatiga is an integrated school for children with special needs, especially mental retardation and autism which are still experiencing problems in the delivery of a lesson to his students. One of the obstacle is to delivery of object recognition. During this time object recognition is done by showing images of objects which are being introduced. For example if we want to introduce animal objects, then the teacher must prepare the object image on the paper in two dimensions and then show it to the students. This method is difficult for the students to recognize objects, because they are children with special needs mental retardation and autism, which have the ability to think below the average of a normal human being. This research aims to design and create an educational game app related to introduction of Object (PO) for children with autism. This educational game utilizes Augmented Reality technology that runs on android mobile devices, so that the object displayed is a three-dimensional (3D), interesting and interactive. The study was conducted in Salatiga Smart House with Children with Special Needs school curriculum as the main reference, especially for elementary school grade 2. The study 
begins by interviewing teachers to find a teaching methods Introduction to Object for children with autism. In addition, interviews are also used to determine the characteristics and levels of autistic children's ability to capture and communicate information. Making this game using Unity $3 D$ main software, Inkscape and Vufori SDK .. This application displays a wide variety of objects of animals, transportation, fruits and vegetables. An object in three dimensions (3D) will be displayed according to the selected marker. It will help teachers and parents in presenting the material and also the children will more easily recognize an object by looking at the application as attractive and as real. Testing is done by demonstrating the application of this educational game for children with autism in Salatiga Smart House, then they are given the opportunity to try out, accompanied by teachers and parents. Based on the results of questionnaires filled out by the teachers and some parents of Smart House, it can be stated that the game is easily played by children with autism. This game is very interesting and can be used by teachers and parents as a medium of learning Introduction to Object.

Keywords: educational games, autism, augmented reality, Unity3D, Inkscape, vuforia.

\section{PENDAHULUAN}

Autisme, merupakan sebuah kondisi yang ditandai dengan adanya gangguan interaksi sosial, komunikasi, dan berpikir abstrak, dan sering dimanifestasikan atau ditunjukkan oleh stereotip berulang. Autis memerupakan suatu kumpulan gejala (sindrom) yang diakibatkan oleh kerusakan saraf dan gangguan tumbuh kembang. Penyandang autism menunjukkan gangguan komunikasi yang menyimpang. Gangguan komunikasi tersebut dapat terlihat dalam bentuk keterlambatan bicara, tidak bicara, bicara dengan bahasa yang tidak dapat dimengerti (bahasa planet), atau bicara hanya dengan meniru saja (ekolalia). Selain gangguan komunikasi, anak juga menunjukkan gangguan interaksi dengan orang disekitarnya, baik orang dewasa maupun orang sebayanya [2].

Perkembangan teknologi informasi telah merambah segala bidang kehidupan termasuk bidang pendidikan. Pengaruh perkembangan tersebut terutama pada isi materi dan proses pembelajaran . Pada tahap sekolah dasar, kecenderungan siswa adalah lebih tertarik pada permainan yang didalamnya terdapat obyek 3dimensi (3D) yang menarik dan mudah dimainkan [5]. Sehingga pada usia sekolah dasar pemberian materi pelajaran akan lebih mudah diterima apabila dirancang dalam sebuah permainan edukatif yang menarik. Permainan edukatif akan menyebabkan siswa secara tidak langsung menerima isi materi yang terdapat dalam permainan. Sedangkan saat ini proses pembelajaran di sekolah masih menggunakan metode pembelajaran konvensional yaitu pembelajaran yang terpusat pada guru dengan beberapa media pembantu seperti buku maupun alat peraga lainya. Seperti contoh, pada pembelajaran pengenalan obyek untuk anak autis tingkat sekolah dasar di Rumah Pintar Salatiga, guru mengandalkan buku dan alat peraga gambar 2 dimensi (2D) untuk mengajar. Metode tersebut saat ini dirasa kurang menarik perhatian siswa dalam mengikuti pelajaran yang berlangsung. Salah satu cara untuk menyajikan pembelajaran yang menarik, penulis menggunakan perkembangan teknologi Augmented Reality (AR) sebagai dasar pembuatan aplikasi game edukasi untuk anak autis tingkat sekolah dasar. Aplikasi game dijalankan pada perangkat mobile android. Pada aplikasi terdapat materi pengenalan obyek hewan, sayursayuran, buah-buahan dan alat-alat transportasi yang disesuaikan dengan kurikulum pembelajaran untuk Anak Berkebutuhan Khusus (ABK).

Augmented Reality (AR) adalah teknologi yang menggabungkan benda maya dua dimensi (2D) dan ataupun tiga dimensi (3D) kedalam lingkungan nyata tiga dimensi (3D) lalu memproyeksikan bendabenda maya tersebut dalam waktu nyata [3]. Pemanfaatan teknologi tersebut memungkinkan menampilkan obyek pembelajaran secara tiga dimensi (3D). Aplikasi game yang dibuat bertujuan untuk mempermudah guru dalam menyampaikan materi pengenalan obyek dan menarik minat belajar siswa autis.

\section{METODOLOGI PENELITIAN}

Metode yang digunakan dalam penelitian ini adalah metode observasi dan wawancara, yaitu dengan menginvestigasi permasalahan yang terjadi pada kegiatan belajar mengajar anak autis kemudian mengidentifikasi penyelesaian yang dapat digunakan untuk mengatasi permasalahan tersebut. Hasil observasi dan wawancara terhadap guru pembimbing pada Sekolah Rumah Pintar Salatiga adalah sebagai berikut :

a. Pendampingan dan pembimbingan diperlukan oleh siswa dalam menyerap materi pembelajaran.

b. Siswa autis umumnya kurang fokus dan cepat merasa bosan pada materi yang disampaikan.

c. Kurikulum pembelajaran anak autis sesuai dengan kompetensi dari Diknas.

d. Setiap kelas dengan jumlah siswa 10-12 dibutuhkan dua guru pembimbing. 
e. Salah satu metode belajar yang diterapkan pada Sekolah Rumah Pintar adalah bermain dengan mengenal gambar.

f. Secara operasional, para guru menghendaki bahwa game yang dibuat mudah digunakan sehingga layak sebagai salah satu media pembelajaran.

\subsection{Perancangan Aplikasi}

Perancangan aplikasi dimulai dengan membuat storyboard untuk game edukasi, yang merupakan serangkaian sketsa visual untuk menggambarkan urutan atau alur dari game edukasi. Storyboard dari game edukasi ditunjukan pada gambar 1 . Terdiri dari 5 scene, yaitu dari scene 0 hingga scene 4 , dengan penjelasan keterangan sebagai berikut :

a. Scene 0 : merupakan menu awal untuk memulai permainan

b. Scene 1 : pengenalan beberapa obyek pembelajaran yaitu buah, sayur, hewan dan transportasi.

c. Scene 2 : merupakan tampilan apabila salah satu menu obyek pada scene 2 dipilih

d. Scene 3 : menampilkan tutorial cara bermain game.

e. Scene 4 : berisi tentang informasi nama game dan tahun pembuatan.

Game ini dijalankan pada perangkat mobile android. Selain itu, untuk memainkan game ini dibutuhkan beberapa marker obyek yang telah didaftarkan di vuforia.com. Cara mengenalkan beberapa obyek dalam game ini adalah dengan mendekatkan kamera perangkat mobile android pada marker obyek yang diinginkan.
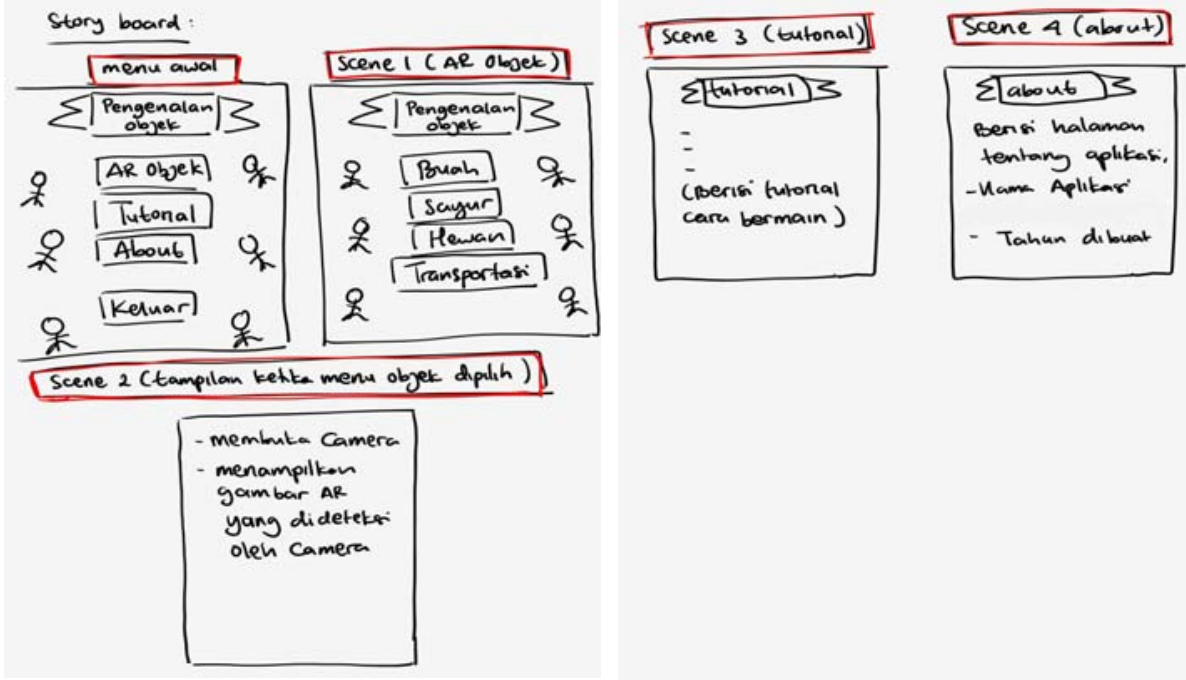

Gambar 1. Storyboard game pengenalan obyek

\subsection{Pembangunan Aplikasi dan Testing}

Aplikasi game edukasi ini dibangun menggunakan perangkat lunak utama Unity 3D, Inkscape dan Vuforia SDK. Langkah-langkah pembangunan aplikasi dapat dijelaskan sebagai berikut :

1) Mendaftarkan beberapa marker yang akan digunakan ke vuforia.com sesuai dengan urutan dan ketentuan yang berlaku, yaitu membuat license manager, membuat target manager dan mengunduh basis data target dari vuforia. Langkah berikutnya adalah mendesain obyek dalam marker, yaitu dengan menyalin license manager dari vuforia sebagai App License Key, lalu meng-import basis data vuforia yang telah diunduh ke basis data aplikasi. Selanjutnya mengatur gambar target dan meng-import obyek tiga dimensi untuk ditampilkan sesuai marker.

2) Beberapa dataset marker akan diberikan pada aplikasi ini sesuai dengan materi pengenalan obyek pada pembelajaran, yaitu dataset marker hewan, buah, sayur dan alat transportasi.

3) Membuat user interface aplikasi sesuai storyboard untuk mempermudah pengguna dalam memainkan game edukasi.

Setelah aplikasi selesai dibangun, selanjutnya diuji di Rumah Pintar Salatiga dengan melibatkan siswa-siswa kelas 2 dan didampingi oleh guru pengajar. Kuesioner diberikan pada para pengajar dan 
beberapa wali murid dengan tujuan untuk menganalisa aplikasi game edukasi yang telah diuji cobakan.

\section{HASIL DAN PEMBAHASAN}

Hasil dari penelitian ini adalah aplikasi Game Edukasi Pengenalan Obyek (PO) untuk anak autis berbasis augmented reality. Ketika memainkan game ini, marker dua dimensi sesuai dengan obyek yang akan ditampilkan harus sudah tersedia, dan pada perangkat mobile android sudah harus terpasang aplikasi game. Berikut pembahasan hasil dari penelitian game edukasi Pengenalan Obyek (PO) untuk anak autis di Rumah Pintar Salatiga.

\subsection{Halaman Awal}

Halaman awal akan muncul pertama kali saat program dijalankan. Halaman awal ditunjukkan pada gambar 2. Ketika halaman ini muncul maka akan terdengar backsound musik sebagai pengiring aplikasi. Ada 4 tombol pada halaman awal, yaitu tombol "AR Objek" untuk memulai permainan, tombol "Tutorial" untuk menampilkan tutorial berbasis teks cara memainkan game dan tombol "Keluar" untuk keluar dari aplikasi.

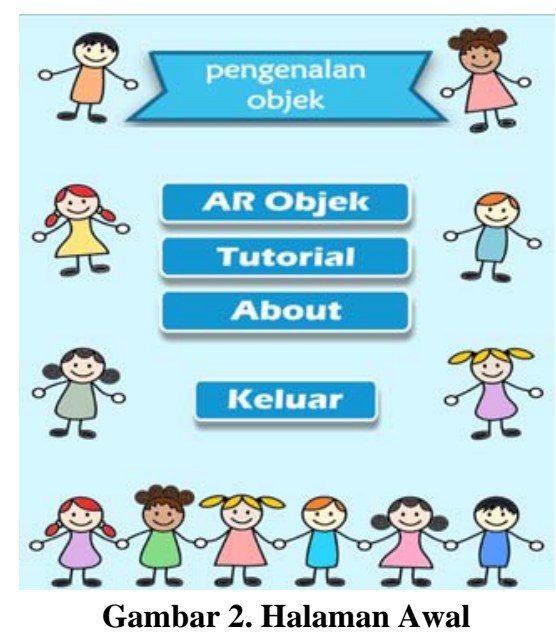

\subsection{Halaman AR Objek}

Halaman AR Objek akan muncul apabila pengguna memilih tombol "AR Objek" pada halaman awal. Halaman ini merupakan halaman utama untuk memainkan game edukasi. Halaman "AR Objek" ditunjukkan pada gambar 3. Ada 4 tombol yang bisa dipilih pada halaman ini, yaitu tombol "Buah", "Sayur", "Hewan" dan "Transportasi".

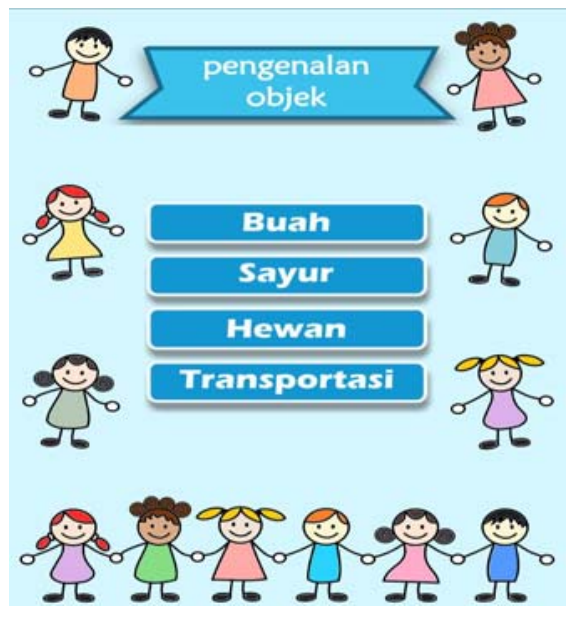

Gambar 3. Halaman AR Objek 


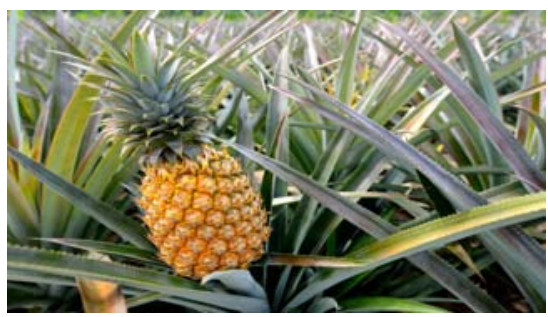

BUAH (NANAS)

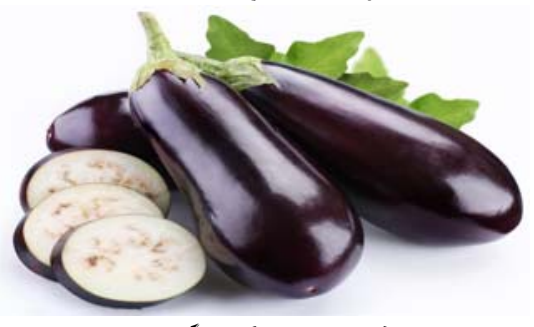

SAYUR (TERUNG)

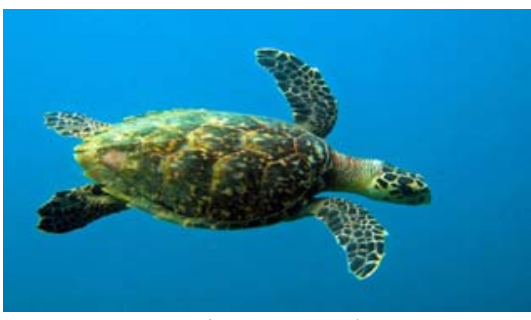

HEWAN (PENYU)

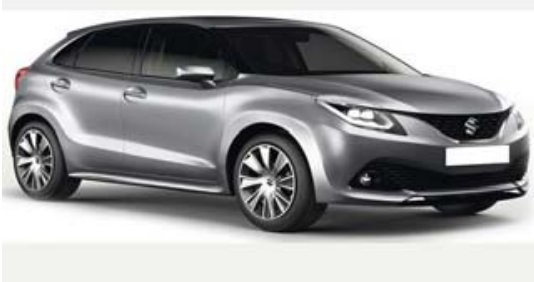

TRANSPORTASI (MOBIL)

Gambar 4. Contoh Marker Buah, Hewan, Sayur dan Transportasi

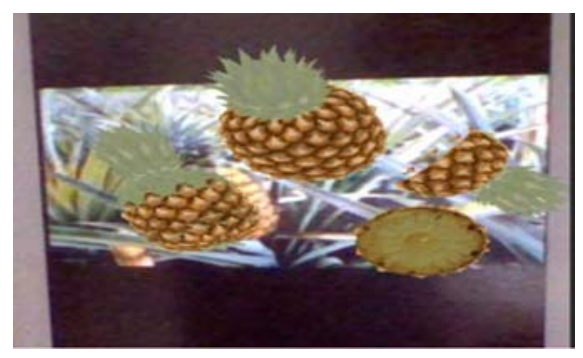

AR BUAH (NANAS)

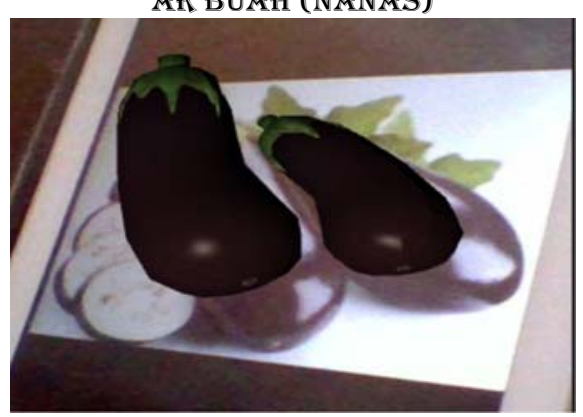

AR SAYUR (TERUNG)

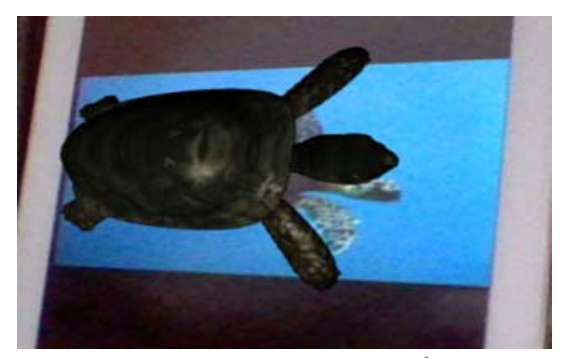

AR BINATANG (PENYU)

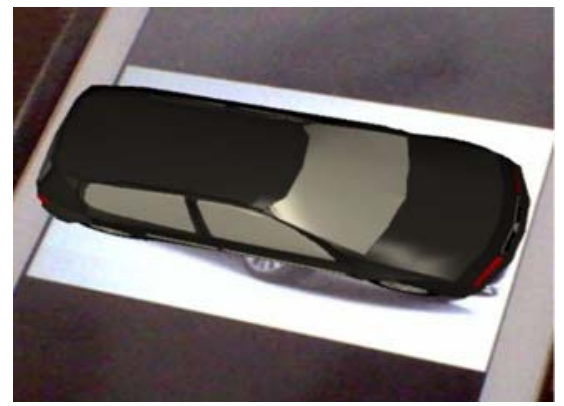

AR TRANSPORTASI (MOBIL)

Gambar 5. Contoh Augmented Reality Buah, Hewan, Sayur dan Transportasi

Berdasarkan kurikulum pembelajaran yang digunakan di Rumah Pintar Salatiga, banyak sekali obyek yang harus dikenalkan pada siswa-siswa autis dan dikelompokkan menjadi 4 kategori, yaitu buah, sayur, hewan dan transportasi. Semua obyek yang akan dikenalkan telah disediakan marker- nya. Maka pengguna harus menyiapkan marker terlebih dahulu sebelum memilih salah satu tombol pada halaman AR Objek. Misalnya, pengguna memilih tombol hewan pada tampilan AR Objek, maka marker yang disiapkan adalah marker kategori hewan. Marker kemudian didekatkan ke kamera perangkat mobile android, dan sesaat kemudian akan muncul gambar tiga dimensi hewan sesuai dengan marker yang didekatkan kamera. Cara yang sama bisa dilakukan untuk melihat obyek dari kategori-kategori yang lain pada aplikasi. Gambar 4 menunjukkan beberapa contoh marker yang bisa digunakan untuk memainkan aplikasi game edukasi untuk anak autis. Sedangkan gambar 5 merupakan contoh tampilan augmented reality tiga dimensi pada perangkat mobile android apabila marker yang sesuai didekatkan pada kamera perangkat tersebut. Obyek tiga dimensi yang ditampilkan bisa diputar hingga $360^{\circ}$, sehingga tampilan menjadi lebih menarik dan obyek tiga dimensi bisa diamati secara lebih detail oleh pengguna. 


\subsection{Halaman Tutorial dan Halaman About}

Halaman tutorial akan muncul apabila pengguna memilih tombol "Tutorial" pada halaman awal. Halaman ini berisi informasi berbasis teks yang menjelaskan cara untuk memainkan game edukasi. Gambar 6a. menunjukkan halaman tutorial yang dimaksud. Sedangkan halaman about merupakan halaman pelengkap dari aplikasi game edukasi. Halaman ini hanya akan menampilkan informasi tentang nama game, peruntukan game dan tahun pembuatan. Halaman ini akan muncul apabila pengguna memilih tombol "About" pada halaman awal, seperti ditunjukkan pada gambar $6 \mathrm{~b}$.
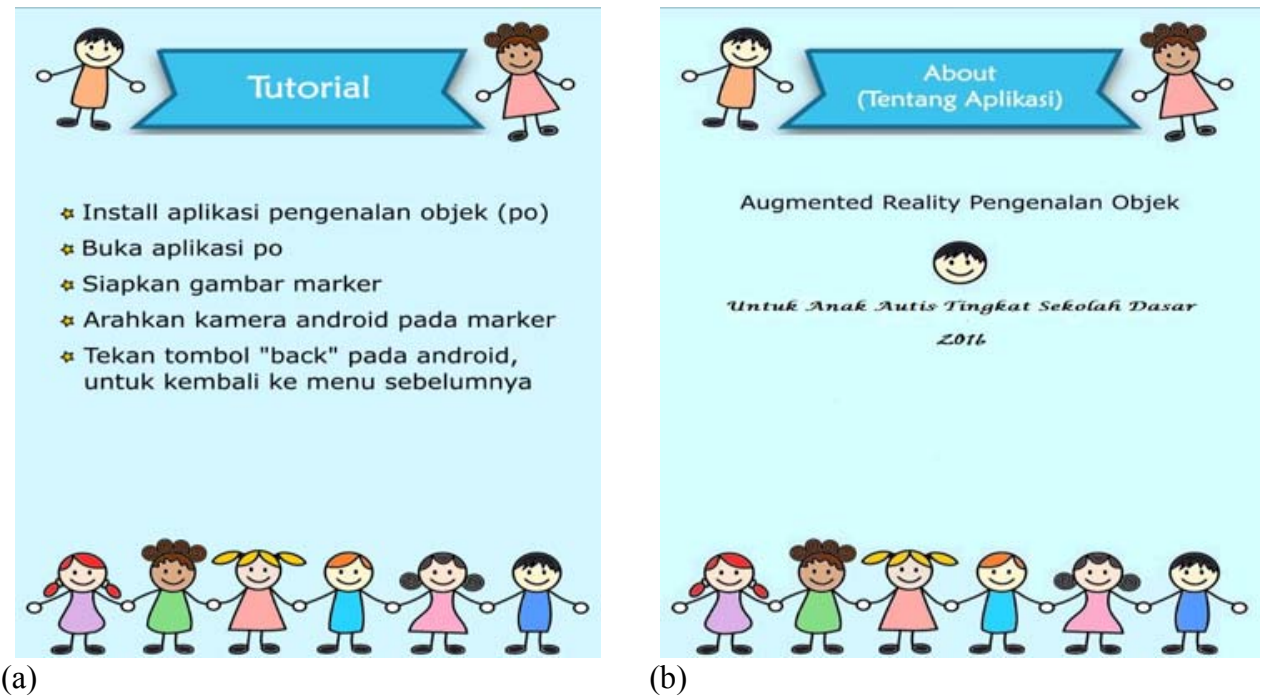

\section{Gambar 6. Halaman Tutorial dan Halaman About}

\section{PENGUJIAN}

Pengujian penelitian ini dilaksanakan di Rumah Pintar Salatiga terhadap siswa-siswa autis kelas 2 Sekolah Dasar, didampingi guru-guru pengajar dan beberapa wali murid.

\subsection{Pengujian Aplikasi}

Pengujian aplikasi pada penelitian ini menggunakan metode black-box untuk mengetahui apakah aplikasi berjalan dengan baik sesuai dengan yang diinginkan atau tidak [1]. Tabel I menunjukkan hasil pengujian aplikasi dengan metode black-box pada halaman awal dan halaman AR Objek.

Tabel 1. Hasil uji black-box pada halaman awal dan AR Objek

\begin{tabular}{|c|c|c|c|c|}
\hline No & Yang diuji & Input & Output & Status \\
\hline 1 & Tombol AR di halaman awal & $\begin{array}{l}\text { Klik tombol AR } \\
\text { Objek }\end{array}$ & $\begin{array}{l}\text { Masuk ke halaman } \\
\text { AR Objek }\end{array}$ & Benar \\
\hline 2 & $\begin{array}{l}\text { Tombol Tutorial di halaman } \\
\text { awal }\end{array}$ & $\begin{array}{l}\text { Klik tombol } \\
\text { Tutorial }\end{array}$ & $\begin{array}{l}\text { Menampilkan } \\
\text { halaman Tutorial }\end{array}$ & Benar \\
\hline 3 & $\begin{array}{l}\text { Tombol About di halaman } \\
\text { awal }\end{array}$ & Klik tombol About & $\begin{array}{l}\text { Menampilkan } \\
\text { halaman About }\end{array}$ & Benar \\
\hline 4 & $\begin{array}{l}\text { Tombol Keluar di halaman } \\
\text { awal }\end{array}$ & Klik tombol Keluar & Keluar dari aplikasi & Benar \\
\hline 5 & $\begin{array}{l}\text { Tombol Buah di halaman AR } \\
\text { Objek }\end{array}$ & Marker buah & $\begin{array}{l}\text { Menampilkan obyek } \\
\text { buah 3D sesuai } \\
\text { marker dan berputar } \\
\text { di android }\end{array}$ & Benar \\
\hline 6 & $\begin{array}{l}\text { Tombol Sayur di halaman AR } \\
\text { Objek }\end{array}$ & Marker sayur & $\begin{array}{l}\text { Menampilkan obyek } \\
\text { sayur 3D sesuai } \\
\text { marker dan berputar } \\
\text { di android }\end{array}$ & Benar \\
\hline
\end{tabular}




\begin{tabular}{lllll}
\hline No & Yang diuji & Input & Output & Status \\
\hline 7 & Tombol Hewan di halaman & Marker hewan & $\begin{array}{l}\text { Menampilkan obyek } \\
\text { hewan 3D sesuai }\end{array}$ & Benar \\
& AR Objek & & $\begin{array}{l}\text { marker dan berputar } \\
\text { di android }\end{array}$ \\
& & Marker transportasi & $\begin{array}{l}\text { Menampilkan obyek } \\
\text { transportasi 3D }\end{array}$ \\
8 & $\begin{array}{l}\text { Tombol Transportasi di } \\
\text { halaman AR Objek }\end{array}$ & & $\begin{array}{l}\text { sesuai marker dan } \\
\text { berputar di android }\end{array}$ \\
& & & \\
& &
\end{tabular}

\subsection{Uji Validitas dan Reliabilitas}

Uji reliabilitas dan validitas digunakan untuk mengukur reliable dan valid tidaknya suatu kuisioner. Pengujian kuesioner dinyatakan reliable apabila jawaban responden terhadap pernyataan adalah konsisten dari waktu ke waktu [4]. Tabel 2 menunjukkan hasil uji validitas kuesioner oleh para guru dan wali murid.

Tabel 2. Hasil uji validitas kuesioner para guru dan wali murid

\begin{tabular}{lccc}
\hline Korelasi antara & Nilai korelasi & Nilai tabel & Kesimpulan \\
\hline P1 terhadap total & 0,662 & 0,553 & valid \\
P2 terhadap total & 0,632 & 0,553 & valid \\
P3 terhadap total & 0,640 & 0,553 & valid \\
P4 terhadap total & 0,919 & 0,553 & valid \\
P5 terhadap total & 0,753 & 0,553 & valid \\
\hline
\end{tabular}

Instrumen pernyataan dinyatakan valid apabila nilai korelasi lebih besar daripada $r$ tabel. Hasil uji validitas yang ada pada tabel 2 menunjukkan bahwa semua instrumen pernyataan adalah valid. Berdasarakan hasil uji reliabilitas dapat dihitung nilai Cronbach Alpha sebesar 0.684. Berdasarkan indeks kriteria reliabilitas, nilai Cronbach Alpha sebesar 0.684 mengindikasikan tingkat reliabilitas yang tinggi. Ini berarti bahwa hasil kuisioner dapat dipercaya dan dapat digunakan sebagai salah satu alat pengumpul data, karena isntrumen pada kuisioner tersebut sudah baik.

\subsection{Pengujian Persentase Interpretasi}

Gambar 8 menunjukkan hasil perhitungan dari kuisioner setelah dilakukan uji validitas dalam grafik persentase.

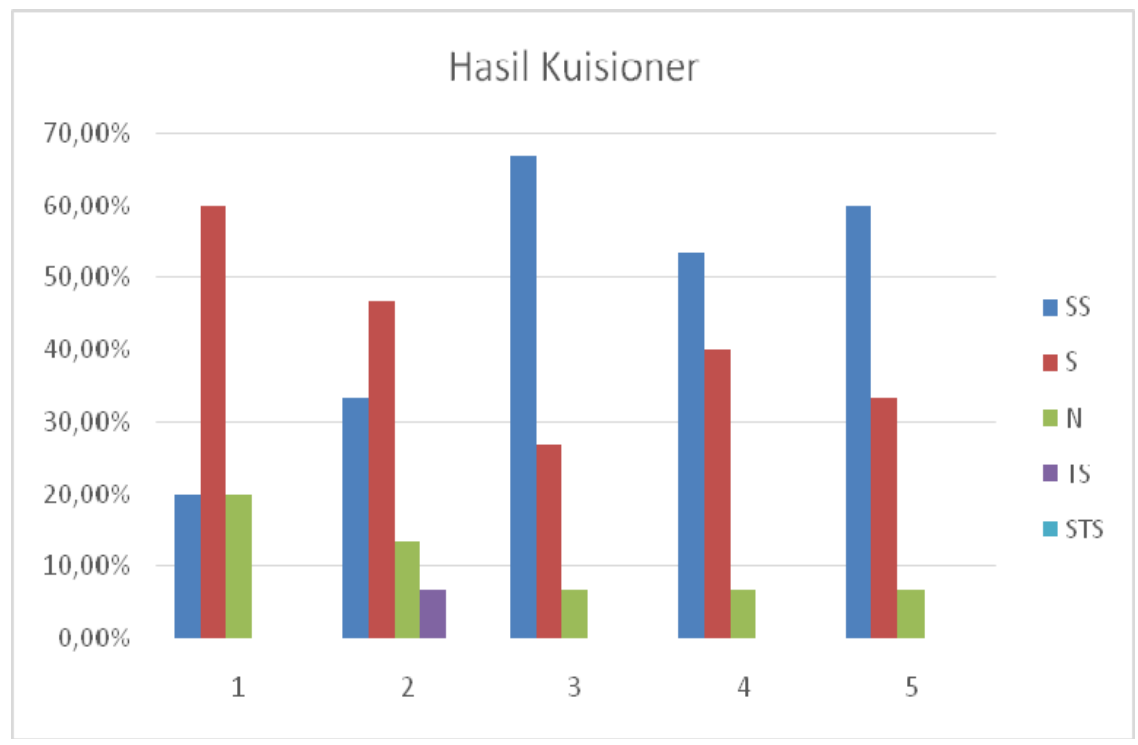

Gambar 7. Grafik Presentase Kuisioner 
Keterangan :

1: Aplikasi mudah digunakan

2 : Tampilan dan isi aplikasi menarik

3 : Aplikasi dapat membantu anak untuk mengenal buah, hewan, sayur dan transportasi.

4: Aplikasi dapat membantu guru untuk memperkenalkan buah, hewan, sayur dan transportasi.

5 : Aplikasi dapat meningkatkan pengetahuan anak tentang buah, hewan, sayur dan transportasi.

Hasil yang didapatkan adalah sebagai berikut :

a. Pernyataan 1 (Aplikasi mudah digunakan) : $60 \%$ responden menyatakan "Setuju", yang menyatakan "Sangat Setuju" dan "Netral" masing-masing 20\%, ini berarti aplikasi mudah digunakan.

b. Pernyataan 2 (Tampilan dan isi aplikasi menarik) : 33,33\% "Sangat Setuju", 46,67\% "Setuju", 13,33\% "Netral" dan 6,67 \% "Tidak Setuju", ini dapat difahami bahwa tampilan dan isi aplikasi menarik.

c. Pernyataan 3 (Aplikasi dapat membantu anak untuk mengenal buah, hewan, sayur dan transportasi ) : 66,67 \% "Sangat Setuju", 26,67\% "Setuju" dan 6,67\% "Netral”, berarti aplikasi dapat membantu anak mengenal obyek.

d. Pernyataan 4 (Aplikasi dapat membantu guru untuk memperkenalkan buah, hewan, sayur dan transportasi) : 53,33 \% "Sangat Setuju", 40\% "Setuju" dan 6,67\% "Netral". Ini berarti aplikasi dapat membantu guru mengenalkan obyek.

e. Pernyataan 5 (Aplikasi dapat meningkatkan pengetahuan anak tentang buah, hewan, sayur dan transportasi) : $60 \%$ "Sangat Setuju”, 33,33\% "Setuju” dan 6,67\% "Netral”. Hasil ini mengandung pengertian bahwa aplikasi dapat meningkatkan pengetahuan anak autis tentang obyek.

\section{KESIMPULAN}

Kesimpulan yang diperoleh dari penelitian ini adalah :

a) Aplikasi Augmented Reality untuk game edukasi memudahkan para siswa autis dalam mengenal obyek tiga dimensi dengan lebih detail.

b) Aplikasi Augmented Reality untuk game edukasi memberikan manfaaat bagi guru dalam menyampaikan materi pengenalan objek yang meliputi binatang, alat transportasi, buah dan sayur. Hal ini dibuktikan dengan hasil yang diperoleh dari kuieioner yang diisi oleh para guru dan beberapa wali murid sebagai responden.

\section{DAFTAR PUSTAKA}

[1] Beizer, B. (1995). Black-Box Testing: Techniques for Functional Testing of Software and systems. New York: John Wiley \& Sons, Inc.

[2] Bimantara, Afif., et al. 2015. "Implementasi Aplikasi Game Autisme "Ahada” Di SLB Bina Anggita Yogyakarta” Jurnal Ilmiah DASI STMIK AMIKOM Yogyakarta 16.2,1-11.

[3] Feiner, F., et al. 1993. "Knowledge-based Augmented Reality," Commun ACM 36. 7, 53-62.

[4] Chen,J., and Gupta,A.K. (2011). Parametric Statistical Change Point Analysis: With applications to Genetics, Medicine, and Finance. New York: Springer.

[5] Sudarmilah, Endah.,et al. 2013." Tech Review: Game Platform for Upgrading Counting Ability on Preshool Children". Proceedings of 2013 International Conference on Information Technology and Electrical Engineering, 226-231. 